\title{
幹線街路周辺における騒音被害の要因分析 \\ AN ANALYSIS OF RESIDENTS' REACTIONS TO TRAFFIC NOISE
}

\section{1.はじめに}

今日の都市内道路交通事情の悪化は，単に交通主体の 側のみならず, 沿道の居住環境の破壊をももたらしてい る。特に, 幹線街路では朝夕のラッシュ時には車があふ れ，周辺の細街路は通り拔けの車の危険にさらされてい る。そして，それらが排出する騒音・排気ガスは住民の 日常生活をおびやかしている。なかでも, 騒音被害は広 範用かつ大量である。

そのような居住環境の破壊に対して, 最近種々の対策 が行なわれているが，いまだ試行錯誤の域を出ていない ように思われる。そうした対策の立遅れの理由の 1 つは 現象の把握に基づく適切な予測手法の開発がなされてい ないことであり，いま1つは被害を定量的に把握して， 有効な対策を導き封すことが十分になされていないこ と, そして, それゆえに道路の郭画者が計画システムの 中に，それら環境要因を組み込めないでいるということ である。

そこで本研究では, 幹線街路㓮辺の騒音による被害を アンケート方法によって調査し, 騒音被害とこれに影響 する各種要因との関係の分析を試み, 騒音防止対策の方 向を検討してみた。まず, 被害意識分布と騒音值との比 較考察を行ない, 次に因子分析法を用いて各種騒音被害 意識の相互関係を明らかにし，さらに林の数量化理論 II 類を用いて各種被害意識に影響をおよぼす種々の要因に ついて分析を行ない, 騒音防止対策の方向について検䛅 した。

* 正会員 工修 名古屋大学助手 工学部土木工学科

** 正会員 工博 名古屋大学助教授 工学部土木工学科
青島縮 次 郎* ・河上: 省 吾** By Naojiro Aoshima and Shogo Kawakami

\section{2. 騒音被害調査の概要}

\section{(1) 調査対象地域}

調查対象地域は 図一1 および 2 に示すように, 名古 屋市東部に位置する千種区 48 町, 昭和区 8 町, 総闻積 493 ha の地域である。主要な街路は調查対象地域の中 央付近を東西に通っている 5 車線の県道名古屋長久手線 (通称, 広小路線), それにほぼ直角に交わる 4 車線の 门道志段味田代線, 市道茶屋ケ坂牛巻線（仏小路線を境 に北方へは 2 車線), 2 車線の市道城山線, また平行して 通っている 2 本線の市道千種隼人町線などである。交通 最党 は広小路線が 3.4 3.8 万台/12 h (以下单位は间 じ), 志段味田代町線が 2.1 2.7, 茶ヶ坆牛巻線が 0.6 〜2.3, 下㮔集人町線が 1.5 であり，あとはす心゙て 0.5 以ドである。用途地域としては幹線街路沿いに近隣商棠 地域が並び, 幹線街路から離机るにしたがって作宅地 域, 第 1 種传:宅専用地城, 第 2 種任: 宅専用地域が続いて

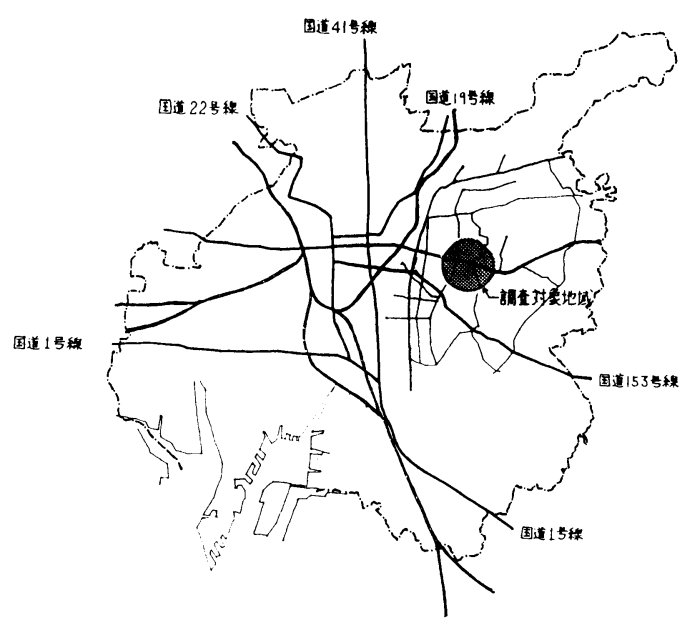

図-1 調查対象地域図 


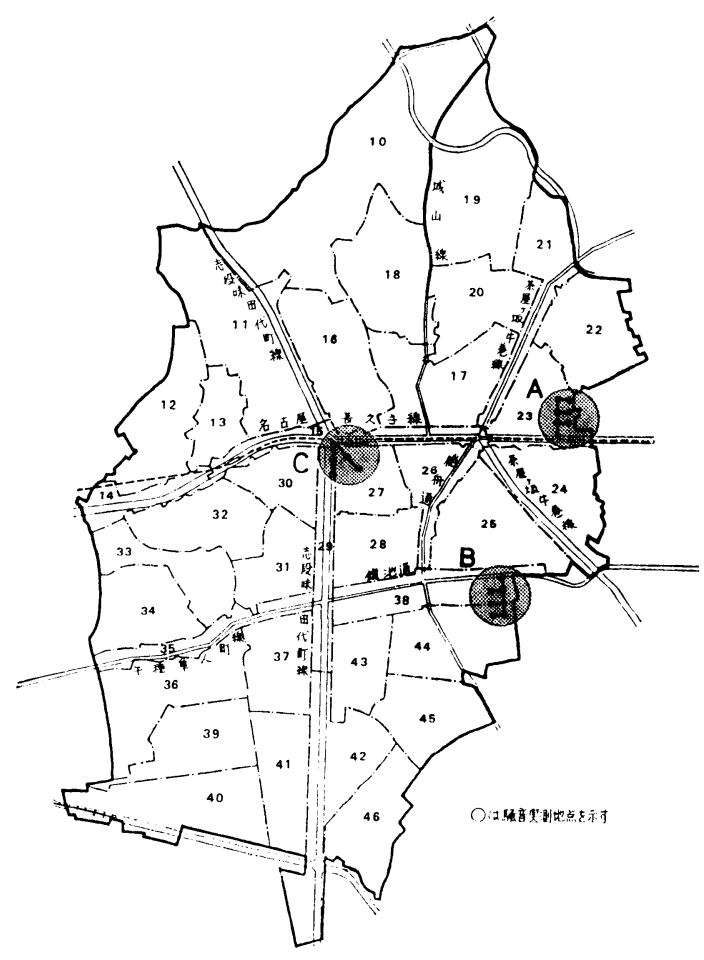

図一2 調查対象地域詳細図

いる地域である。近隣商業地域の中で, 広小路線沿いに 第 3 次産業の集積が見られるほかは目立った商店街がな いといら, 典型的な住宅地域である（なお，調查は同時 に名古屋市中村区の住商工混合地域でも行なわれたが, この結果については別の機会に譲りたい)。

\section{（2）アンケート調查}

調查対象地域の 20103 世帯について 住民登録台帳よ り $5 \%$ のランダム抽出を行ない，985 世帯の標本を用 意した。調査は，ほかに徒歩トリップを中心にしたパー ソントリップ調查と合わせて行なったため, 調查日を昭 和 46 年 7 月 6 日火曜日と限り, それ以前に調査票を各 家庭に配布し, 調査日の次の日から回収に回るといら家 庭訪問法をとった。調査日の天候は日中は晴れていた が,夕方一時にわか雨があった。回収世帯は891 世帯（回 収率は 90.5\%) で, 騒音被恝の 調查対象年齢 12 歳以 上の回答者は 2317 人であった。

アンケート項目 ${ }^{3}$ は 図一3に示すように, 道路交通騒 音による被害の回答をできるだけ歪めないように，まず 一般的な騒音被害について質問し, 続いて道路交通騒音 の被害について質問するようにした。また，家の中での 騒夏被害について回答するよらに注意を払った。質問内 容 ${ }^{4}$,5) としては, 道路交通騒音による聴覚妨害, 思考妨 害, 睡眠妨害, 情緒的影響, 身体的影響を中心にして,

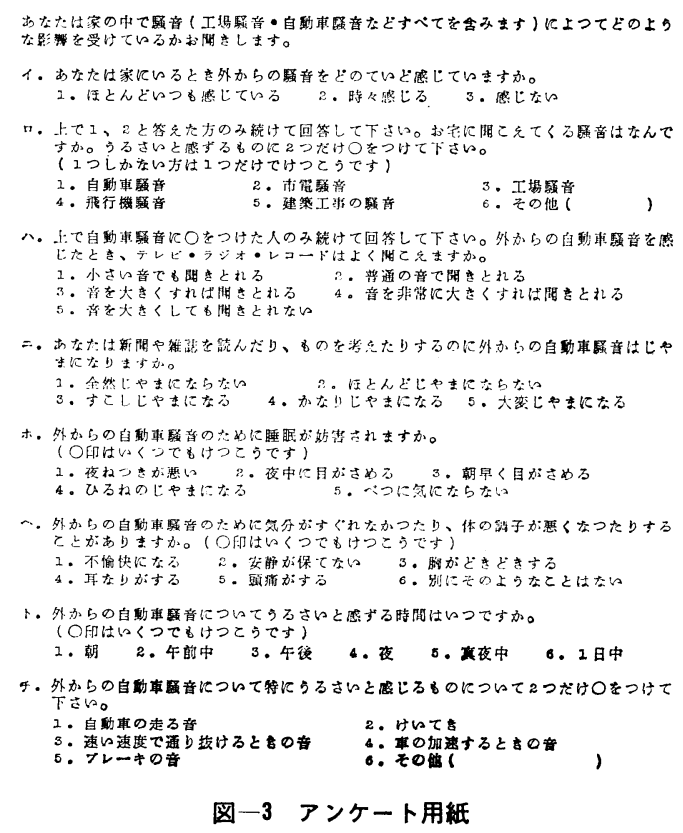

このほか騒音被害の時間带, 道路交通騒音の種類などを とりあげた。

\section{(3) 騒音実測}

調查は昭和 48 年 1 月 19 日に, 図一2 で示した $\mathrm{A}$, $\mathrm{B}, \mathrm{C}$ の 3 地点で午前 1 回, 午後 2 回の 騒音実測を行な った。天候は晴で, 風はほとんどなかった。調査地点 $\mathrm{A}$ は広小路線, $\mathrm{B}$ は鏡ケ池通から值角方向に 3 ブロック (1ブロックは約 $50 \mathrm{~m}$ の幅をもっている) 入った地点 まで測定を行ない，幹線街路を見通すことのできる細街 路トで 4 点, 見通すことのできないブロックの内部中閒 地点の細街路上で 3 点の騒音值を得た。また, 調査地点 Cは, 㕕小路線と志段味田代町線との交差点付近で, 街 路に沿って 2 点ずつ, ブロックの内部へ 2 点の騷音值を 得た。測定方法は JIS Z 8731 にしたがって1回につい て各点 5 秒おきに 60 個の騒音值を読み, 中央值を求め た。そして, 阔洔に幹線街路の 5 分閒交通量を測定し た。

\section{3. 騒音被害の実態}

\section{（1）各種被害の地域分布}

図一2 で示したような，町を主体にしたゾーンについ て, 道路交通騒音による被害, そしてまた聴覚妨害, 思 考妨害, 睡眠妨害, 情緒的影響, 身体的影響を訴える人 のパーセントを示したのが 図一4 である。このとき， 聴覚妨害, 思考妨害については質問八. ニ.の解答 3 . 


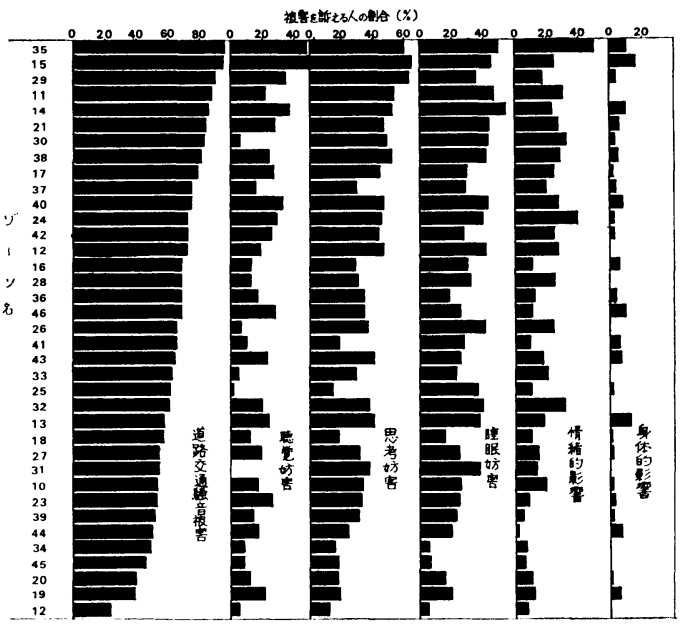

図-4 各種被害の地域分布

4.5.に○をつけた人は被害ありとし, 睡眠妨害につい

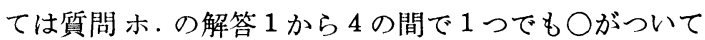
いれば被害ありとした。また, 情緒的影響, 身体的影響 は質問人.の解答 1 . と 2., 3. と 4. と 5. のそれぞれ に1つでも○がついていれば被害ありとした。

これを見ると, 道路交通騒音による被害は, 幹線街 路, それも 4 車線以上の街路周辺のゾーンに高い比率で 現われているのがわかる。各種被害の中でこれと同じよ うな傾向を示しているのが聴覚妨害, 思考妨害, 睡眠妨 害であり，情緒的影響と身体的影響は傾问をとらえるこ とは難しい。また, 各種被害を受けている人の比率は, 全ゾーンを通じて思考妨害が最も大きく，続いて睡眠妨 㗉, 聴覚妨害, 情緒的影響の順に小さくなり, 最も小さ いのが身体的影響である。以下，より詳しい分析につい ては 4.に譲る。

な抢，ここで留意しなけ机ばならないことは，これら の被夆は幹線街路からの騒音のみならず，地域内一㚈人 りする車の騒音による被圊も加算されていることであ る。しかし, 今後の分析に抢いては, それを幹線街路に 付属する騷音と考えて分析を進める。

\section{（2）幹線街路周辺の騒音值}

図一5 に実線，破線で示したのが各実測地点 $\mathrm{A}, \mathrm{B}$, $\mathrm{C}$ の騷音值である。実測地点 $\mathrm{A}, \mathrm{B}$ において，実線で 示したのは幹線街路を見通すことのできる細街路上での 測定結果であり，破線は見通すことのできないブロック 内部の細街路上での測定結果である。また, 実測地点 C

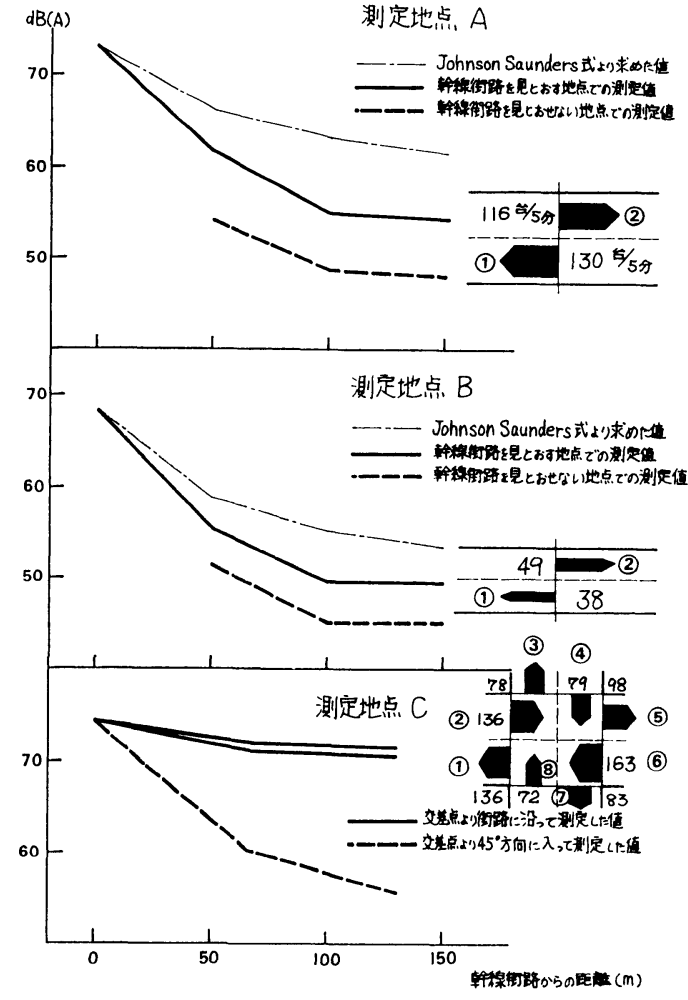

図一5幹線街路周辺の騷音值

における実線は，上が交差点より南方に，下が東方に向 って街路沿いに測定した結果であり, 破線は交差点より $45^{\circ}$ 方向に入った交差点を見通せる細街路上での測定結 果である。各地点とも 3 回の奏測の際の交通量に顕著な 違いが見られないため，騒音做は 3 问の実測の中央值の 平均值で，交通量は 3 回の測定の平均值で示した。その ときの車種構成を 表一1 に示す。また 1 点鎖線で示し たのが，開いた空間における騒音の中央值を子測する式 として一般的に用いられている Johnson Saunders の 式に車種構成の影響を導入した式 $(1)^{6)}$ と重ね合せ式 $(2)^{7)}$ で求めた騷音值である。

$$
\begin{aligned}
L_{M i}= & 10 \log _{10} \frac{N_{i}}{l_{i}}+30 \log _{10}\left(\frac{V_{i}}{60}\right) \\
& +10 \log _{10}\left(1+0.05 a_{i}\right)+45 \cdots
\end{aligned}
$$

ここで $N_{i}$ は $i$ 車線の交通量 (台/h), $l_{i}$ は $i$ 車線から の距離 $(\mathrm{m}), V_{i}$ は $i$ 車線の走行速度 $(\mathrm{km} / \mathrm{h}), a_{i}$ は $i$ 車線の大型車混入率 (\%) で, $L_{M i}$ が $i$ 車線からの騒 音の中央值 $(\mathrm{dB}(\mathrm{A}))$ である。そして式 (1) を用いて

表一1 幹線街路交通の車種栱成

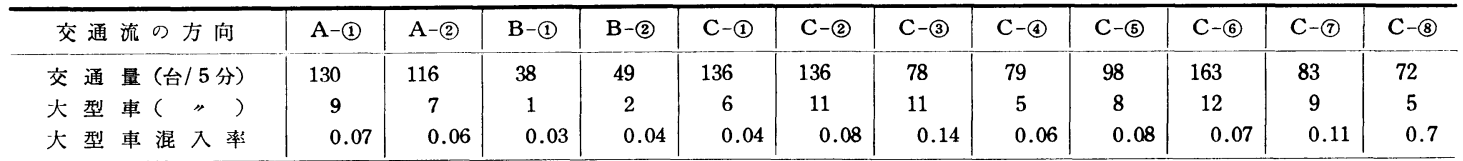


求めた各車線からの騒音値を式（2）で重站合せる。

$$
\begin{aligned}
L_{M}= & 10 \log _{10}\left(10^{L_{M_{1} / 10}}+10^{L_{M_{2}} / 10}+\cdots\right. \\
& \left.+10^{L_{M i} / 10}+\cdots\right) \cdots \cdots \cdots \cdots \cdots \cdots
\end{aligned}
$$

ここで $L_{M_{1}}, L_{M_{2}}, \cdots, L_{M i}$ は各車線からの騒音值であ る。計算に際しては 表一1 の各值を用いた。交通量は 各車線に等配分し, 走行速度はすべて $40 \mathrm{~km} / \mathrm{h}$ とした。

実測地点 $\mathrm{A}, \mathrm{B}$ の結果を見ると, 幹線街路より直角方 向に入ると,中央值は著しく減少し, Johnson Saunders の式より求めた值と比較しても，その差は $3 \sim 4 \mathrm{~dB}(\mathrm{~A})$ から 6 7 $\mathrm{dB}(\mathrm{A})$ 一と拡がってゆく。街路から 2 ブロ ック以上離れると暗騒音が卓越し, 中央值ではほとんど 幹線街路からの騒音の影響は現われてこない。こうした 結果の理由として, 距離による騒音減衰と, 家屋による 遮音効果があげられる。ブロック内部での測定結果は, より顕著に家屋による遮音効果が現われている。このと

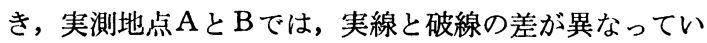
るが，これは実測地点 $\mathrm{A} の$ 街路に面したブロックの家屋 が 2 階建の鉄筋コンクリート構造であり, 実測地点 Bで はそれが木造平屋建になっているためと考えられる。

実測地点Cについては, 発進騒音が加わっているとと

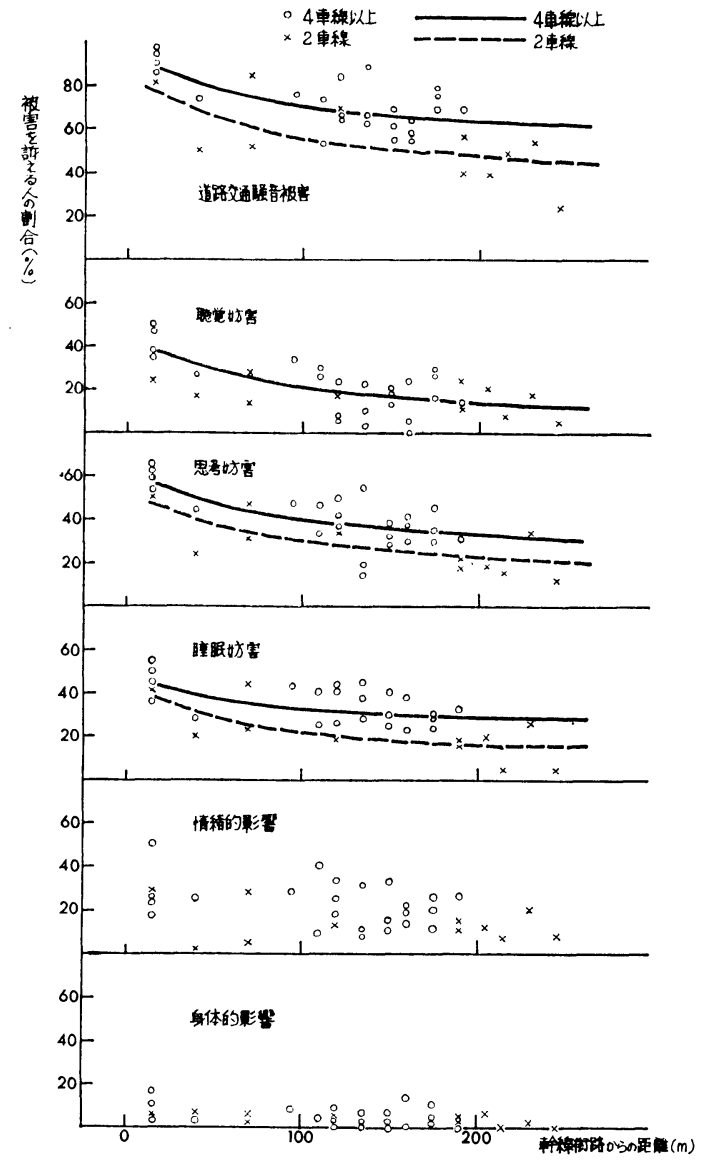

図一6 車線数と蜸音被害分布
もに常に高密な車団波となって車群が流れるために，実 測地点 $\mathrm{A}$ と比較して $2 \mathrm{~dB}(\mathrm{~A})$ ほど高い騒音値を示して いる。交差点より街路沿いに測定した結果を見ると，交 通量が少ないほらがかえって騒音值が高くなっている。 これはもっとも近い車線の発進車団波が発進してすぐの ものでパワーレベルが小さい状態と，発進してすでにか なり加速したものでパワーレベルが大きくなっている状 態との差があらわれたものと思われる ${ }^{8)}$ 。 なお, 交差点 から $45^{\circ}$ の方向に入った紐街路上:での測定結果は, 他地 点 $\mathrm{A}, \mathrm{B}$ と同じような傾向を示しているといえる。

\section{4. 騷音被害の要因分析}

\section{（1）街路交通亡騷音被害分布 ${ }^{9)}$}

ここではまず, 幹線街路の街路交通要因と周辺の各種 騒音被害の分布状況との関連を概略的にとらえてみた い。街路要因として車線数, 交通要因として交通量をと った。また 幹線街路周辺の被害の分布は 図一2 に示し

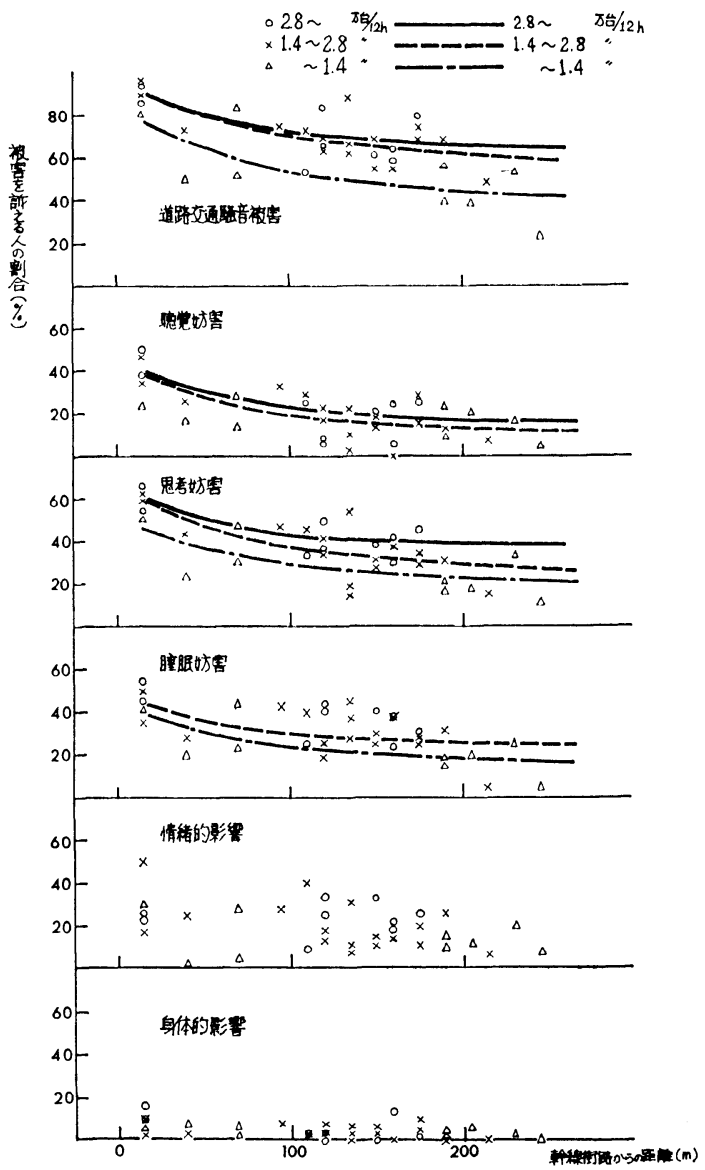

図一7 交通量と䮣音被害分布 
た各ジーンを単位にして，その中心から最む近い幹線街 路をでの距離をとり，その距離をゾーンと幹線街路の平 均的な距離と考えた。

図一6 は幹線街路の車線数と各種被害の分布の関倸 を, 図一7は幹線街路の交通量と各種被害の分布の関係 を示したものである。ここで, 車線数は 4 車線以上と 2 車線の 2 つに分け，また交通量は 1 万台 $/ 12 \mathrm{~h}, 2$ 万台/ $12 \mathrm{~h} ， 4$ 万台 $/ 2 \mathrm{~h}$ ，の 3 段階にわけ，その分割点を 1.4 万台 $/ 12 \mathrm{~h}, 2.4$ 万台 $/ 12 \mathrm{~h}$ とした。なお，対数表示した 幹線街路からの距離上各ジーンの騒音被害率の間に危険 摔 $5 \%$ で有意な相関があると検定されたものについて は，四帰線を記人しておいた。

図一6によれば，車線数と道路交通騒音の被害に一い ては，路側付近で，10\% ほど 4 車線以上のほうが滆く, 路側より $200 \mathrm{~m}$ 地点で約 $15 \%$ と差が抎がっている。 また各種被害については，思考妨害，睡眠妨害について 対数表示された距離との間に有意な相関が認められ，前 者に扔いては路側から $200 \mathrm{~m}$ 地点まで, 一定して約 10 \% の差が見られる。後者に抒いては, 路側でほぼ一致 し, 離れるにしたがって差が生じて $200 \mathrm{~m}$ 地点では約 15\% の差となっている。その他の被害については，車 線数との有意な相関が認められず，その他の要因が強く きいてきていると考えられる。

図一7 の交通量と道路交通騒音の被害については, 交 通量が 1.4 万台 $/ 12 \mathrm{~h}$ 以上では被害の差はほとんど見ら れず, 1.4 万台 $/ 12 \mathrm{~h}$ 以下とは路側において $10 \%$ ほど， $200 \mathrm{~m}$ 地点で $20 \%$ ほどの差が生じている。また各種被 㕩については，思考妨害についてのみ対数表示された距 離との間にそれぞれの交通量において有意な相関が認め られ，3 分類の交通量に対して，ほぼ $10 \%$ ずつの差が 生じている。

\section{（2）各種被害の相互関係}

前節までの分析では各種被害を単独で扱ってきたが， ここではこれらの被害要因がどのような相互関係を有し ているのかを，因子分析法 ${ }^{10)}$ を用いて検討した。データ としては道路交通騒音の被害がありと答え,なおかつ， 各種被害について明確にあるか，ないかを答えたものを 排いた。データ数は 196 人で，聴覚妨害があるとした ものがその5ち 115 人，思考妨害が 161 人，睡眠妨害 が 196 人, 情緒的影響が 83 人，身体的影響が 44 人で あった。

ここで，睡眠妨害は全員がありと答えている。3，の （1）では思考妨害がもっとも多かったが，その他の被害 については不明と答えているものまで含めているからで ある。つまり，騒音被害について明確に回答をしている 人にとって睡眠妨害がもっとも被害の根幹となっている
表 2 各種被害要因の因子負荷量

\begin{tabular}{|c|c|c|c|}
\hline 騷音被害要因 & $\begin{array}{l}\text { 第 } 1 \text { 因子 } \\
\text { 負 荷量 }\end{array}$ & $\begin{array}{l}\text { 第 } 2 \text { 因子 } \\
\text { 龔 }\end{array}$ & $\begin{array}{l}\text { 第3因子 } \\
\text { 賁 荷 }\end{array}$ \\
\hline 德 党 妨 害 & 0.785 & 0.114 & 0.134 \\
\hline 思考 妨 害 & 0.662 & -0.313 & 0.636 \\
\hline 情 緒 的 影 響 & 0.603 & 0.615 & -0.417 \\
\hline 身体的影䈉 & 0.566 & -0.659 & -0.484 \\
\hline 累積説明力 (\%) & 43.5 & 64.5 & 85.3 \\
\hline
\end{tabular}

と考えられる。

睡眠妨害については全員がありと答えているので，こ れを除外し，4つの被害要因について分析を行なった。 その結果を表一2 に示す。これを見ると第 3 因子まで で $85.3 \%$ の説明尔示しており，第 1 因子は $43.5 \%$ の説明力を持っている。

第 1 因子については，そり負何量の間に顕著な差が見 られず，4つの被害要因は同時に現われる傾问にあるこ とを示している。しかし，ここで第 1 因子を横軸に，第 2 因子を縦軸にして負荷量をプロットした 図一8 を見 ると，情緒的影響と聴覚妨害は第 1 象限に，身体的影響 と思考妨害は第 4 象限に表われている。つまり，情緒的 影響と聴覚妨害，そして身体的影響と思考妨害は同じ傾 向の被害と考えられ，それらの被害は同時に生じやすい といえる。いうまでもなく,これらの被害は，いずれも 睡眠妨害と同時に発生している。

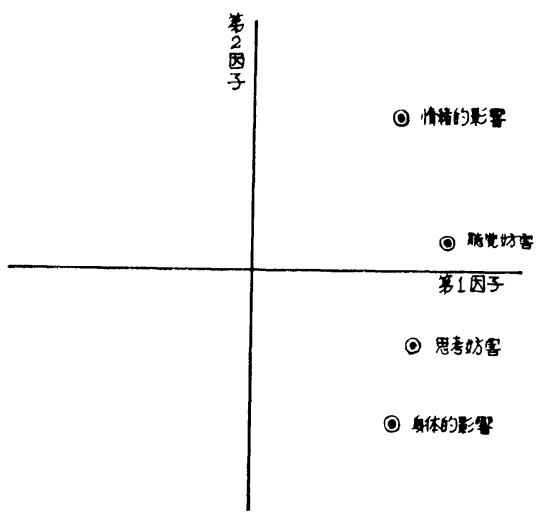

図-8 各被害要因の位置

\section{（3）各種被害の要因分析}

林の数量化理論 ${ }^{11}$ は多数の定性的属性の各力テジリ一 に適当な数值を与えて, 定量的変数と同様に多变量解析 を施すことができるという利点を持っている。4．の(1) で, 各種騒音被害と幹線街路からの距離との関係を, 東 線数と交通量をパラメーターとして分析したが，特に情 緒的影響, 身体的影響については別の要因が強くきいて いると考えられた。また騒音の被害は，住居の立地条件 がきわめて大きく影響するので, ゾーンの被害率として 騒音被害を把握した場合, その要因分析には限界があ 
り, 咩細な要因の分析は個人を対象として行なら必要が ある。そこで個人属性, 世帯属性, 地理的属性を加え, 林の数量化理論類を用いて, 個人の被害を対象として さらに詳しい分析を行なった。このとき, 各属性の選択 においては被害を減少させるのに寄与すると考えられる 要因を選ぶように注意を払った。

分析に用いた属性は以下のとおりである。

a）個人属性……年齢, 性別, 職業の有無（3 アイテ 厶)

ここで職業の有無を採用したのは，昼間家に居るかど らかで騒音被害が異なるかどうかを知りたかったからで ある。

b）世帯属性……住宅構造，住宅形式（2ケ.イテム）
住宅形式とは，専用住宅，併州位:先かである。

c）地理的属性……交通量, 空間距離, ブロック内 外, 前面の住宅の構造, 交差点付近か (5 アイテム)

この地理的属性はすべてもっとも近い幹線街路に関す る事項およびそれからの地理的関係を示している。ブロ ック内の位置とは幹線街路を見通すことのできる細街路 に沿って住居があるか，見通せない位犆に住居があるか である。前面の住宅の構造とは, その住居から幹線街路 に向いたとき, 幹線街路に沿って建っている家が 1 階 か， 2 階か， 3 階以上の鉄筋かである。また最後の項目 において, 交差点付近とは幹線街路の信号設置点を中心 にして 1 ブロック以内（約 $50 \mathrm{~m}$ 以内）にあるものをい う。このほかに幹線街路の本線数についても検咕した

表-3 各要因のレンジと順位

\begin{tabular}{|c|c|c|c|c|c|c|c|c|c|c|c|c|}
\hline \multirow[b]{2}{*}{ アイテム } & \multirow[b]{2}{*}{ カ デリ } & \multirow[b]{2}{*}{$\begin{array}{l}\text { サンプ } \\
\text { ル数 }\end{array}$} & \multicolumn{2}{|c|}{ 聴賞妨害 } & \multicolumn{2}{|c|}{ 思考佑害 } & \multicolumn{2}{|c|}{ 睡眠妨害 } & \multicolumn{2}{|c|}{ 情緒的影響 } & \multicolumn{2}{|c|}{ 身体的影響 } \\
\hline & & & 数 值 & $\begin{array}{l}\text { レンジ } \\
\left(\begin{array}{c}\text { その } \\
\text { 䐓位 }\end{array}\right)\end{array}$ & 数 值 & $\begin{array}{l}\text { レンジ } \\
\left(\begin{array}{c}\text { その } \\
\text { 順位 }\end{array}\right)\end{array}$ & 数 伹 & $\begin{array}{l}\text { レンジ } \\
\left(\begin{array}{c}\text { その } \\
\text { 順位 }\end{array}\right)\end{array}$ & 数 值 & $\begin{array}{l}\text { レンシ } \\
\left(\begin{array}{c}\text { その } \\
\text { 順位 }\end{array}\right)\end{array}$ & 数 值 & $\begin{array}{l}\text { レンシ } \\
\left(\begin{array}{c}\dot{*} \% \\
\text { 順位 }\end{array}\right)\end{array}$ \\
\hline 年 齢（歳） & $\begin{aligned} & \sim 20 \\
21 & \sim 30 \\
31 & \sim 40 \\
41 & \sim 50 \\
51 & \sim 60 \\
61 & \sim\end{aligned}$ & $\begin{array}{r}83 \\
138 \\
113 \\
91 \\
77 \\
70\end{array}$ & $\begin{array}{r}0.041 \\
0.177 \\
-0.004 \\
-0.073 \\
0.012 \\
-0.081\end{array}$ & $\begin{array}{c}0.258 \\
(5)\end{array}$ & $\begin{array}{r}0.051 \\
0.124 \\
-0.069 \\
0.051 \\
0.008 \\
-0.086\end{array}$ & $\begin{array}{c}0.210 \\
(5)\end{array}$ & $\begin{array}{r}0.067 \\
0.042 \\
-0.041 \\
0.021 \\
0.023 \\
-0.089\end{array}$ & $\begin{array}{c}0.156 \\
(7)\end{array}$ & $\begin{array}{r}0.007 \\
0.076 \\
0.023 \\
0.022 \\
-0.015 \\
-0.058\end{array}$ & $\begin{array}{c}0.134 \\
(7)\end{array}$ & $\begin{array}{r}0.057 \\
0.192 \\
-0.060 \\
0.069 \\
-0.087 \\
-0.089\end{array}$ & $\begin{array}{c}0.281 \\
(3)\end{array}$ \\
\hline 性 別 & $\begin{array}{l}\text { 男 } \\
\text { 女 }\end{array}$ & $\begin{array}{l}280 \\
292\end{array}$ & $\begin{array}{r}0.075 \\
-0.085\end{array}$ & $\begin{array}{c}0.160 \\
(8)\end{array}$ & $\begin{array}{r}0.059 \\
-0.067\end{array}$ & $\begin{array}{c}0.126 \\
(8)\end{array}$ & $\begin{array}{r}0.064 \\
-0.072\end{array}$ & $\begin{array}{c}0.136 \\
(8)\end{array}$ & $\begin{array}{r}0.034 \\
-0.038\end{array}$ & $\begin{array}{l}0.071 \\
(10)\end{array}$ & $\begin{array}{r}0.081 \\
-0.091\end{array}$ & $\begin{array}{c}0.172 \\
(7)\end{array}$ \\
\hline 職業の有無 & 有 & $\begin{array}{l}303 \\
269\end{array}$ & $\begin{array}{r}-0.023 \\
0.021\end{array}$ & $\begin{array}{l}0.044 \\
(10)\end{array}$ & $\begin{array}{r}-0.005 \\
0.005\end{array}$ & $\begin{array}{l}0.010 \\
(10)\end{array}$ & $\begin{array}{r}-0.009 \\
0.008\end{array}$ & $\begin{array}{l}0.017 \\
(10)\end{array}$ & $\begin{array}{r}-0.041 \\
0.036\end{array}$ & $\begin{array}{c}0.077 \\
(9)\end{array}$ & $\begin{array}{r}-0.005 \\
0.004\end{array}$ & $\begin{array}{l}0.009 \\
(10)\end{array}$ \\
\hline 住宅の形式 & $\begin{array}{ll}\text { 専 用 住 宅 } \\
\text { 併 用 住 宅 }\end{array}$ & $\begin{array}{r}503 \\
69\end{array}$ & $\begin{array}{r}-0.036 \\
0.268\end{array}$ & $\begin{array}{c}0.304 \\
(3)\end{array}$ & $\begin{array}{r}-0.043 \\
0.327\end{array}$ & $\begin{array}{c}0.370 \\
(2)\end{array}$ & $\begin{array}{r}-0.036 \\
0.272\end{array}$ & $\begin{array}{c}0.308 \\
(3)\end{array}$ & $\begin{array}{r}-0.019 \\
0.144\end{array}$ & $\begin{array}{c}0.163 \\
(4)\end{array}$ & $\begin{array}{r}-0.034 \\
0.255\end{array}$ & $\begin{array}{l}0.289 \\
(2)\end{array}$ \\
\hline $\begin{array}{l}\text { 交 通 星 } \\
(\text { 万台 } / 12 \mathrm{~h})\end{array}$ & $\begin{aligned} 2 & \sim \\
1 & \sim 2 \\
0.5 & \sim 1 \\
& \sim 0.5\end{aligned}$ & $\begin{array}{r}216 \\
83 \\
143 \\
130\end{array}$ & $\begin{array}{r}0.032 \\
-0.247 \\
0.071 \\
-0.011\end{array}$ & $\begin{array}{c}0.318 \\
(2)\end{array}$ & $\begin{array}{r}0.058 \\
0.045 \\
-0.193 \\
-0.041\end{array}$ & $\begin{array}{c}0.251 \\
(4)\end{array}$ & $\begin{array}{r}0.060 \\
0.057 \\
-0.102 \\
-0.066\end{array}$ & $\begin{array}{c}0.162 \\
(6)\end{array}$ & $\begin{array}{r}0.023 \\
-0.117 \\
0.016 \\
-0.007\end{array}$ & $\begin{array}{c}0.140 \\
(6)\end{array}$ & $\begin{array}{r}0.061 \\
-0.143 \\
-0.017 \\
-0.002\end{array}$ & $\begin{array}{c}0.204 \\
(5)\end{array}$ \\
\hline $\begin{array}{c}\text { 空間距 離 } \\
\text { (m) }\end{array}$ & $\begin{aligned} & \sim 15 \\
16 & \sim 30 \\
31 & \sim 60 \\
61 & \sim 120 \\
121 & \sim 200\end{aligned}$ & $\begin{array}{r}87 \\
36 \\
108 \\
190 \\
151\end{array}$ & $\begin{array}{r}0.355 \\
0.063 \\
0.017 \\
-0.052 \\
-0.120\end{array}$ & $\begin{array}{c}0.475 \\
(1)\end{array}$ & $\begin{array}{r}0.293 \\
0.158 \\
0.085 \\
-0.075 \\
-0.146\end{array}$ & $\begin{array}{c}0.439 \\
(1)\end{array}$ & $\begin{array}{r}0.252 \\
0.226 \\
0.078 \\
-0.154 \\
-0.164\end{array}$ & $\begin{array}{c}0.416 \\
(1)\end{array}$ & $\begin{array}{r}0.129 \\
0.145 \\
0.009 \\
-0.068 \\
-0.014\end{array}$ & $\begin{array}{c}0.159 \\
(5)\end{array}$ & $\begin{array}{r}0.400 \\
-0.158 \\
0.128 \\
-0.047 \\
-0.189\end{array}$ & $\begin{array}{l}0.589 \\
(1)\end{array}$ \\
\hline $\begin{array}{l}\text { ソロック内 } \\
\text { の位 置 }\end{array}$ & $\begin{array}{l}\text { 街路に面している } \\
\text { 街路を見とおせる } \\
\text { 街路を見とおせない }\end{array}$ & $\begin{array}{r}82 \\
211 \\
279\end{array}$ & $\begin{array}{r}0.134 \\
0.021 \\
-0.055\end{array}$ & $\begin{array}{l}0.189 \\
(6)\end{array}$ & $\begin{array}{r}0.134 \\
0.038 \\
-0.068\end{array}$ & $\begin{array}{c}0.202 \\
(7)\end{array}$ & $\begin{array}{r}0.203 \\
0.006 \\
-0.064\end{array}$ & $\begin{array}{c}0.267 \\
(4)\end{array}$ & $\begin{array}{r}0.181 \\
-0.016 \\
-0.041\end{array}$ & $\begin{array}{l}0.222 \\
(2)\end{array}$ & $\begin{array}{r}0.144 \\
0.012 \\
-0.051\end{array}$ & $\begin{array}{l}0.195 \\
\text { (fi) }\end{array}$ \\
\hline 前面の構造 & 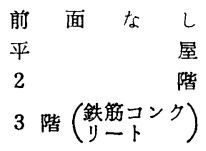 & $\begin{array}{r}105 \\
241 \\
165 \\
61\end{array}$ & $\begin{array}{r}0.092 \\
-0.037 \\
-0.093 \\
-0.069\end{array}$ & $\begin{array}{c}0.185 \\
(7)\end{array}$ & $\begin{array}{r}-0.070 \\
0.107 \\
-0.101 \\
-0.079\end{array}$ & $\begin{array}{c}0.208 \\
(6)\end{array}$ & $\begin{array}{r}0.093 \\
-0.072 \\
-0.100 \\
-0.056\end{array}$ & $\begin{array}{c}0.193 \\
(5)\end{array}$ & $\begin{array}{r}0.102 \\
-0.067 \\
-0.078 \\
-0.075\end{array}$ & $\begin{array}{c}0.180 \\
(3)\end{array}$ & $\begin{array}{r}0.143 \\
-0.123 \\
0.063 \\
0.082\end{array}$ & $\begin{array}{l}0.266 \\
(4)\end{array}$ \\
\hline $\begin{array}{l}\text { 交差点付近 } \\
\text { か }\end{array}$ & $\begin{array}{l}\text { 交差点付近である } \\
\text { 交差点付近でない }\end{array}$ & $\begin{array}{r}67 \\
505\end{array}$ & $\begin{array}{r}0.047 \\
-0.006\end{array}$ & $\begin{array}{c}0.053 \\
(9)\end{array}$ & $\begin{array}{r}0.039 \\
-0.005\end{array}$ & $\begin{array}{c}0.044 \\
(9)\end{array}$ & $\begin{array}{r}0.058 \\
-0.006\end{array}$ & $\begin{array}{c}0.066 \\
(9)\end{array}$ & $\begin{array}{r}0.110 \\
-0.015\end{array}$ & $\begin{array}{c}0.125 \\
(8)\end{array}$ & $\begin{array}{r}0.001 \\
-0.010\end{array}$ & $\begin{array}{l}0.011 \\
(9)\end{array}$ \\
\hline & & & $\eta=0$ & & $\eta=0$ & & $\eta=0$. & & $\eta=0$ & & $\eta=$ & \\
\hline
\end{tabular}


が，交通量と有意な相関が罗られたためここでは削除し た。また幹線街路から何ブロック目に位置するか, とい う項目もとったが, 空間距離によるほらがより正確に判 別できることがわかったので空間距離をとった。

以上の 10 アイテムについて分布を行なった。総力テ ゴリーは 表一3 に示すように 35 である。

データは，以上の各アイテムについてすべて明確に回 答しているものを用いた。また幹線街路から $200 \mathrm{~m}$ 以 上離れれば，幹線街路からの騒音被害はほとんど受けな いと思われるので，それらのものはデータから除いた。 その結果データ数は 572 であった。そのうち聴覚妨書: がありとしたものが 76 人, 思考妨害では 110 人, 睡眠 妨害は 135 人, 情緒的影響が 52 人, 身体的影響が 32 人であった。

计算結果を 表一3 に分す。思考妨害の相関比が 0.528 ともっとも高く, つづいて睡眠妨邫が 0.520 , 聴覚妨㫪 が 0.446 , 情緒的影響が 0.373 , 身体的影響が 0.285 と なっており, 思考妨害, 睡眠妨害, 聴覚妨害の他は十分 に判別が成功しているとはいえない。身体的影響につい ては被害を訴えるデータ数そのものが少ないから, 参考 程度に考えるといら必要があるだろう。なお, 判断の分 点と判断成功率は 表一4 に示すとおりである。

\section{表-4 判断の分点と判断成功率}

\begin{tabular}{|c|c|c|c|c|c|}
\hline 判断要因 & 聴党妨害 & 思考妨害 & 睡眠妨害 & $\begin{array}{l}\text { 情緒的 } \\
\text { 影 響 }\end{array}$ & 身体熘 \\
\hline $\begin{array}{l}\text { 判 断 0) 分 点 } \\
\text { 判断成功棌 (\%) }\end{array}$ & $\begin{array}{l}-0.008 \\
66.5\end{array}$ & $\begin{array}{l}0.021 \\
72.9\end{array}$ & $\begin{array}{c}-0.018 \\
70.1\end{array}$ & $\begin{array}{l}0.005 \\
62.7\end{array}$ & $\begin{array}{l}0.086 \\
70.2\end{array}$ \\
\hline
\end{tabular}

表一3に掠てレンジのトに（）でポしたのが，六 の被暃に影響をおよぼす要因の順位である。騒音被害全 体についていえることは, 幹線街路からの距離, 住:宅構 造, 住宅形式, 交通量が上位を占め, それらが大きく影 響していることがわかる。住宅形式が上位になったこと は, 併用住宅が幹線街路に面しているためと思われる。 一力, 年跉, 性別, 職業の有無などの個人属性は, ほと んどの被害において下位となっており，影響が小さいこ 上がわかる。

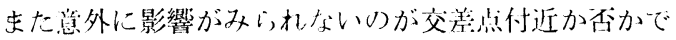
ある。こ机は交差点に抢ける発進騒音を意識する以面 に，一般似な車の赽行騒音としで急識されるためと焽才 れる。ここでは小していないが，発進騒摬に対する被些 を地汹にプロットしたところ，かえって地区内のほうが 多かったくらいである。これと同様に前面の構造につい ても影響があまり見られないが，これは 3 階以上の建物 があるところは第 3 次産業の集積のあるところで, 当然 種々のアクティビティが考えられ, そのため減音効果が 制り引かれて出ていると思われる。これについては别に
精植される必要があるだろう。

個々の被慧について見るならば，前 3 つの被慧はほぼ 问じようなパターンを示しているが，2 位になっている のが聴覚妨害については交通量, 思考妨害については住 宅形式, 睡眠妨害については住宅構造となっている。ま た睡眠妨害の 4 位がブロック内の位置になっているのは 注目される。情緒的影響については, 住宅構造がもっと も強い影響を与えており, 次にブロック内の位置, 前面 の住宅の構造と続いており，他と異なったパターンを示 している。また身体的影響についても, やはり空間距離 がもっとも強く影響している。これはもっともきつい被 㫪であるが, データも少なく相関比も低いため, さらに 個人の健康状態などを要因として入れて再分析する必要 があるだろう。

睡眠妨㫪については，も，上も基本となる被菁なので さらに検討を加えた。すなわちレンジの順位の低い順に 1 つずっ要因を落としていき, 判断成功率が $2 \%$ 以上 さがるところまで計算を繰返し, それより上位になる要 四は被害に対して明らかに影響を与えていると考える。 その結果, 年:齢より上位の要因は睡眠妨害に対して有意 なる影響を与えていることが判明した。そのなかで空間 距離, 住宅構造, 交通量の 3 要因について, 騒音対策を 施した場合の効果を, 表一4 の判断の分点を利用して試 算した。空間距離については, 街路から $15 \mathrm{~m}$ までのと ころに住んでいる人を $30 \sim 60 \mathrm{~m}$ のところまで離した場 台に，それらの人のなかで $26 \% 6$ の人が被害を訴えなく なり，また住宅構造を木造 1 戸建から鉄筋コンクリート 1 个建に変えた場合, 変えた人のなかで $54 \%$ の人が被 菶を訴えなくなると推測できる。そして交通量を 1〜2 万台/12h から $0.5 \sim 1$ 万台/12h に減少させた場合, 被彗を訴えている人の $36 \%$ が被害を訴えなくなる，上 いうことが期待できるといえるだろう。

\section{5. 結語}

以上の調查分析の結果から以下のことが結論ゔけられ る。

（1）道路交通騒音による被邫は，やはり幹線街路周 辽に集中して垷われ, 特に聴覚妨害, 思考妨致, 睡眠妨 等はその傾问が顕著である。情緒的影響，身体的影響に ついては, 幹線街路周辺に集中する傾问はあまり見られ ない。

（2）幹線街路周辺の騒音值は, 街路を兒とおせる地 点では前面の家屋の減衰効果により, 理論値よりも $4 \sim 8$ $\mathrm{dB}$ 小さくなっている。また，家屋に隠れて見とおせな い地点ではさらに $4 \sim 8 \mathrm{~dB}$ 小さい値となっている。そ して, その減衰富は前面の家屋の構造によって異なる。 
（3）幹線街路からの騒音り中央傾ははぼ2ゾロッ ク離れれば暗騒音の域に人ってしまうが，道路交通騒咅 の被害を訴える人はなお半数以上存在する。

（4）幹線街路の車線数が 4 車線以上から 2 車線にな ると，それによる騒音被害は路側で $10 \%, 200 \mathrm{~m}$ 離れ た地点で $15 \%$ ほど減少する。また交通量が 4 万台 $/ 12 \mathrm{~h}$ から 2 万台 $/ 12 \mathrm{~h}$ では顕著な減少を示さないが, 2 万台/ $12 \mathrm{~h}$ 加ら 1 万台 $/ 12 \mathrm{~h}$ になれば路側で $10 \%, 200 \mathrm{~m}$ 地 点で $20 \%$ ほど減少する。

（5）道路交通騒音被青の川でも睡眠妨書はも，上も 根幹をなすものであり，また聴覚妨青と情緒的影響，思

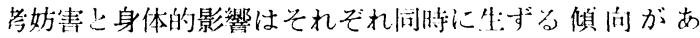
\%。

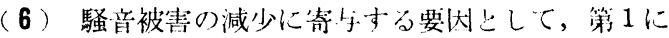
あげられるのはやはり幹線街路からの距離であり，続い て住宅構造，幹線街路の交通量である。睡眠妨青につい ては，住宅構造を木造 1 户建から鉄筋コンクリート 1 广 建に変えた場合，変えた人のうち $54 \%$ が被菁を訴えな くなり，また交通量を $1 \sim 2$ 万台/ $12 \mathrm{~h}$ から $0.5 〜 1$ 万 台 $/ 12 \mathrm{~h}$ に減少させた場合，被害を訴えている人の $36 \%$ が被害を訴えなくなり，そして幹線街路からの距離を路 側 15 m から 30〜60 m まで離した場合，26\%の人が 被害を訴えなくなるといらことが期待されると試算され た。また，幹線街路に面する建物の構造も，騒音被害の 減少に寄与する要因として期待できることがわかった。

最後に，本研究を進めるにあたって終始ご協力くださ

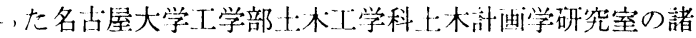
氏に，また数量化理論について種々ご教六くださった徳 島大学:1:学蔀才:木几学科の藤目節夫助手に染く感謝する 次第である。また，本研究を行ならに際しては，多古屋
大学大型計算機 センターの FACOM 230-60 を利用し た。

\section{参 考 文献}

1）青島縮次郎・河上省吾・三星昭宏：名古屋术に打洨 通実態調查について一その 2 調沓内容，昭和 46 年度土木 学会中部支部研究発表会講演概 要 集, pp. 93 94, 㽗和 46.11

2) 名古屋书: 昭和 46 年度一般交通量調查概要, 名古屋㶦, 昭和 47.6

3）大阪市総合計画局公害対策部：大阪书における用途地域 別騒音調査報告書，大阪市，昭和 43.6

4) 山本剛大：騒音の影響と許“容值, 騒音・振動公害, 上小 学会関徆文部，pp. 112 130, 炤和 43.3

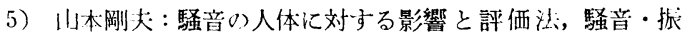
動公害，土木学会関西支部，pp. 39 56, 昭和 47.3

6) 日本音響学会・道路騒音調査研究委員会: 道路騒音調査 報告書，日本音響学会，pp. 16 24, 昭和 44.3

7）山本剛夫：交通騒音一特に自動車騒音について…, 宗都 大学工学部大学開放講座, pp. $348 \sim 349$, 昭和 46.3

8）建設省上木研究所道路部交通環境研究空：昭和 46 年度拭 験調查（交通騒音）報告，士林研究所資料第 763 点, $\mathrm{rp}$. $12 \sim 22$, 昭和 47.6

9）青島縮次郎・古市正敏：道路交通騒音に関する住民の被 害意識について，昭和 47 年度土木学会中部支部研究発表 会講演概要集, pp. 169 170, 昭和 48.2

10) 浅野長一郎：因子分析法通論, 共立出版, pp. 19 47, 昭和 46.8

11）林知已犬・村山孝：市場調查の画と策際，日刊工業新 聞社, pp. $122 \sim 167$, 昭和 39.8

12）筞田 栄：騒音と騒音防止，オーム社，昭和 36.6

13）日本音響材料協会：騒音対策ハンドブック，技報堂，昭 和 41.12

14）安田三郎：社会統汁学, 丸善, 詔和 44.1

15) Colin G. Gordon, et al. : Highway Noise-A Design Guide For Highway Engineers, Highway Research Board, 1971

16) William J. Galloway, et al. : Highway Noise-Measurement, Simulation, And Mixed Reaction, Highway Research Board, 1969

(1973.3.23 - 受付) 